\title{
COMPARATIVE LAW IN LEGAL EDUCATION
}

\author{
JOEN N. HAZARD*
}

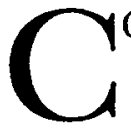

OMPARATIVE law is much in the news. The Association of American Law Schools has held a summer institute to discuss the subject of its teaching, and another is planned. ${ }^{.}$The first printing of a casebook on the subject has just occurred. ${ }^{2}$ Several other comparative law casebooks are being used in mimeographed form. ${ }^{3}$ An International Committee for Comparative Law has been organized under the auspices of UNESCO ${ }^{4}$ with eleven national committees as members. ${ }^{5}$ Three more national committees await only formal establishment to be admitted. ${ }^{6}$ The American Foreign Law Association has expanded its membership and qualified as the representative of comparative law specialists in the United States on the International Committee. ${ }^{7}$

The International Bar Association gave much of the agenda of its third conference in London last July to the subject of comparative law, ${ }^{8}$ and in cooperation with the International Committee for Comparative Law, devoted one day to the subject of comparative law in legal education. The Third Congress of Comparative Law, held in London lașt August, brought together the comparatists of most of the world, and provided an agenda with ninety-five subjects of discussion. ${ }^{9}$

*Professor of Public Law, The Russian Institute, Columbia University.

I The record of the first institute is available as "Summarized Proceedings of the Institute in the Teaching of International and Comparative Law Held under the Auspices of the Association of American Law Schools, August 23-September 4, I948."

"Schlesinger, Comparative Law, Cases and Materials (1950).

3 For example, Rheinstein, The Law of Torts, Cases and Materials from Common Law and Civil Law Countries (r947), and Hazard and Weisberg, Cases and Readings on Soviet Law (1950).

4 For statements concerning its activities, see $x$ International Social Science Bulletin: UNESCO, No. 3-4, at 9 I (r949), and 2 ibid., No. r, at $\mathrm{r}_{44}$ ( $\left.\mathrm{r}_{95} \mathrm{O}\right)$. See also 2 Revue Internationale de Droit Comparé, No. 2, at 328 (April-June, 1950).

5 Belgium, France, Germany, Greece, Guatemala, Haiti, Italy, Nicaragua, Peru, United States, Uruguay.

${ }^{6}$ Brazil, Mexico, United Kingdom.

7 See American Foreign Law Association, Bulletin (Spring, r950).

${ }^{8}$ See International Bar Association, Third International Conference of the Legal Profession, London-1gth-26th July, I950. Programme. (I950). Documents of the conference are available at the Office of the Secretary General, 5or Fifth Avenue, New York, N.Y.

9 See Académie Internationale de Droit Comparé, Questions Inscrites au Programme du Troisième Congrès International de Droit Compare, Londres, 3 I Juillet-5 Aout r950. (I950). 
An incomplete list of cases involving matters of foreign law in American courts has recently been published to show that fifty-six decisions have been rendered in the field in the federal and New York courts during the last year. ${ }^{\text {Io }}$ The International Law Association with a long record of world congresses will add "Comparative Law" to its title and give added emphasis to this aspect of its work. The American Bar Association has restored a Comparative Law Division to its Section of International and Comparative Law and has revitalized the work of the Division. Comparative law is being taught in twenty-six law schools in the United States, ${ }^{\text {II }}$ and many of these are now uniting in a plan to publish an American Journal of Comparative Law, probably beginning in I95x.

A record of this character has excited considerable interest. Not only legal scholars but practitioners as well are showing concern. Outsiders have begun to ask what is afoot, and why such interest. A stocktaking is perhaps in order to determine where the subject now stands as a discipline in the law school curricula and where it may be expected or required to progress in the future. This paper is intended as a contribution in that direction.

\section{The Practical Approach}

Few law school deans have yet been sufficiently concerned with comparative law to think of the subject as more than a scholarly embellishment in the catalogue of those who are rich enough to afford it. One eminent dean some ten years ago told the author, perhaps facetiously, that comparative law was of little value except to add a scholarly touch to a footnote in a law review article.

As a result of the attitude of the deans, the necessity of making a place for comparative law on practical grounds has been uppermost in the minds of those who believe that the subject has a place in the curriculum..$^{12}$ The utilitarian approach seems to have motivated the author of the first printed casebook in comparative law. ${ }^{\mathrm{x}}$ This new book devotes its first and final thirds to the types of problems in foreign and comparative law which can be expected to confront the American practitioner. Judicial decisions are reproduced to indicate the difficulties to be expected in proving foreign law, and specific questions which arise most frequently are presented in detail. Thus, the materials discuss techniques of proof of foreign law such

\footnotetext{
30 See American Law Association, Bulletin (Spring, I950).

"See Stevenson, Comparative and Foreign Law in American Law Schools, 50 Col. L. Rev. $61_{3}(1950)$.

${ }^{22}$ See ibid., at 6r4.

${ }^{3}$ Schlesinger, op. cit. supra note 2.
} 
as the use of official declarations of what the law is, and the conduct of direct and cross examination of foreign-law experts. The specific fields of law selected for treatment are contracts, agency, corporations, and conflict of laws. Any practitioner having clients engaged in international trade, or owning shares in foreign corporations requiring administration upon the client's death knows that these questions are not academic. They are a very real part of the practice in many law offices of New York, Boston, Chicago and San Francisco, and even of law offices in the smaller cities which have become manufacturing centers with an export trade or homes for first generation Americans.

Similar practical considerations have led to the giving of courses in the commercial law of civil law countries. The teacher of such a course believes that the student can be expected to meet some of the problems discussed in the course when he graduates. ${ }^{14} \mathrm{He}$ is fitted to correspond intelligently with his colleagues in Brazil or France and to have a better chance of success in avoiding pitfalls than his brother at the bar who knows only about the common law.

A similarly practical use of the materials of foreign law and the comparative method is to be found in the field of administrative law. In the field of public corporations the experience in the United Kingdom is becoming increasingly well documented, ${ }^{15}$ and the experience of the USSR is extensively discussed. ${ }^{16}$ While both countries espouse a nonprivate enterprise program, their experience with state-owned industry is revealing to those who consider problems of management in those spheres in which the government-state or federal-has taken its place even in the United States.

The administration of housing during periods of shortages can be studied to great advantage with materials from the experience of Germany after the first World War, or England and the USSR, both of which have faced severe shortages. Students who may be expecting to prepare themselves for a place in any of the legal departments of government agencies can profit from such materials quite as well, if not better than if they were required to concern themselves with estates in land or the administration of wills with which they will never be concerned.

14 For example, the courses in Columbia and New York Universities based upon the commercial law of civil-law countries, discussed in Stevenson, op. cit supra note rx.

Is See for example, 2x Political Quarterly No. 2 (April-June I950), devoted to Nationalized Industries in the United Kingdom, and Robson, Nationalized Industries in Britain and France, 44 Am. Pol. Sci. Rev. 299 (I950).

${ }^{16}$ See I Gsovski, Soviet Civil Law, Chap. Ir (I950). 
A less practical reason is widely espoused for some of the other courses which appear in law school curricula. While actually less directly practical, the reason for these courses is nevertheless such as to require classification under the rubric "the practical approach." It is maintained that a course in the comparative approach to law aids the common-law student in comprehending his own system of law better than would otherwise be possible if the student never stood aside and viewed it from the vantage point of a system of law entirely foreign to it. Thus, the student who faces the law of torts as developed in the common-law countries may be able to reconsider the rule relating to the duty to act and the inroads that have been made upon it with a fresh approach when he considers the law on the subject in Europe. ${ }^{17}$ The reason for the preservation of the doctrine of consideration in the law of contracts may be questioned when the civil law, which purports to do without it, is considered. The concept of individual ownership of property by each spouse takes on clarity when compared with the community property concept of the civil law.

By studying differing treatment of familiar questions the student is expected to ask himself why a rule has developed, and in so doing to fix the rule firmly in mind. He also is believed to do more. He is believed to develop his own reasoning process so that he passes beyond the level of the parrot to the level of the thinking being. He experiences some of the excitement claimed for the study of the "Great Books," long espoused by the University of Chicago's Chancellor. With the Great Books course the student is led through the thinking process of a Euclid, a Newton or a Galileo in the conception of a theory that is now taken for granted in the usual classroom. He asks himself how the frontiers of knowledge have been pushed forward and thus develops the feeling that frontiers can be pushed forward and are not comprised of immutable principles which must be accepted on faith and which thereafter provide the corners of his world. The student of comparative law can expect the same return from his facing of common-place problems as if they were new and from following the reasoning of the civil-law lawyers in devising rules to meet them.

\section{THE THEORETICAL APPROACH}

The student who has reviewed the practical questions of international trade, or the understanding of the rules of the common law relating to consideration or contributory negligence, will usually not stop with the prac-

${ }^{27}$ See materials in Rheinstein, op. cit. supra note 3, at 82 . 
tical question of the rules. He will pass over into the realm of legal theory. He will begin to ask the larger question of the function of law itself. Some of the students of a particularly philosophical bent will ask about the nature of law when they have questioned its function. At this point comparative law becomes a tool in the teaching of legal philosophy.

It is as a tool for the teaching of legal philosophy that comparative law has found its place in some law schools. ${ }^{18}$ Sometimes the course is called "law and society" or "jurisprudence," and the fact that it is the comparative study of law is left for the student to discover as he progresses. This is the theme of the monumental casebook of Simpson and Stone ${ }^{x 9}$ and of the course in jurisprudence at California..$^{20}$

Comparative law, with its nondescript title and reputation as a subject for advanced scholars alone, can be brought before many students when placed in the subject matter of the more familiar courses mentioned. This can be done to an even greater extent when these courses are made compulsory as is becoming the situation in several schools. The nature and function of law becomes of interest to the student who sees for himself that different schools of law have reached different conclusions on a practical problem because of their differing conceptions on this score.

Some teachers have argued that the advantages of the comparative approach in teaching should not be confined to the course on jurisprudence but extended to all courses in the law school. It has been said that time is so limited and resistance of students so great in many schools that no single course in comparative law can be expected to reach more than a handful of men and women. In consequence the teachers of common-law subjects should be given instruction in the approach of foreign systems to the subjects with which they are concerned. ${ }^{2 x}$ Presumably, a teacher who knows the other approaches to torts or contracts or sales will incorporate remarks flowing from his meditation upon the differences or similarities he has found, which will prove stimulating to the student and cause him also to meditate on the function and nature of law. Comparative law will have served its purpose indirectly, but more effectively than has been possible with the direct approach, because more students will be subjected to its influence.

\footnotetext{
${ }^{18}$ See Ehrenzweig, Teaching "Integration"-A Comment on Law and Society, 2 J. Legal Education 359, 36I (I950).

19 Simpson and Stone, Cases and Readings on Law and Society (x949).

${ }^{20} \mathrm{~A}$ paper on the subject was read at the International Bar Association's meeting in London, 1950 .

${ }^{2}$ Ibid.
} 
The suggestion that comparative law be introduced indirectly met with such acclaim at the I950 London sessions of the International Bar Association and the International Committee on Comparative Law that a resolution was proposed urging the establishment in each law school of a chair for the instruction of members of the faculty in that aspect of foreign law which pertains to the fields with which they were primarily concerned. While the resolution carried the meeting, it failed in the House of Deputies of the International Bar Association for lack of sufficient information upon it. Nevertheless, the presentation of the resolution succeeded in putting before the profession a desirable way of utilizing the field of comparative law in broadening horizons in the field of legal philosophy.

\section{The Political Approach}

Since World War II, the subject of comparative law has been receiving increasing attention for another reason, the political one. The preparatory committee which met at the UNESCO conference to form an International Committee for Comparative Law in March, I949, sounded the keynote in its final declaration. The committee declared, "We are of the opinion that the legal profession throughout the world owes a duty to the peoples from which it springs to unite in an effort to overcome such of the tensions and misunderstandings rending the world community as lie within its special spheres of competence.' ${ }_{22}$ The program for action urged research, publication and teaching in comparative law as a means of achieving these ends.

To the lawyers from various legal systems and countries assembled at the preparatory committee meeting the political purpose of comparative law was unification of peoples to the extent possible and elimination of tensions arising from differences where those differences were so firmly rooted in cultures that unification was unlikely within any foreseeable future.

Under this concept the comparative-law course must be designed in part to aid the future practitioner and scholar to participate in active movements toward unification such as those currently in progress in spheres of commercial law and in the application of rules of conflict of laws. The unification effort is not only of value in devising the "ideal" rule of law, but it is of value in practice as well, as indicated by the large number of practitioners who attend international congresses devoted to the subject and the large number of states who support agencies working on

${ }_{23}$ Text of declaration reprinted in part in Schlesinger, op. cit. supra note 2, at $3^{\circ}$. 
unified codes and statutes. ${ }^{23}$ The work of unification is already so well known that it hardly requires elaboration. In some measure it leads toward the world of simplified international intercourse which has been the goal of the United States since the end of World War II, and which has found its reflection on the purely governmental level in such efforts as the proposed International Trade Organization designed to eliminate the barriers created by governments.

In the opinion of those who believe that world peace can be furthered by world trade (and there are many hard-headed business men in the United States who hold that view) ${ }^{24}$ efforts to simplify such intercourse, by unification of commercial law, would aid considerably in reducing tensions which can lead to armed conflict. Courses in comparative law which prepare the student to meet eventually with those skilled in the movement for unification and to further its progress along intelligent and informed lines make useful future private diplomats for the United States. Such courses become indirectly instruments of the peace policy of the nation.

Yet all law is not subject to unification, as has been widely appreciated in the past few years. Some law is so firmly rooted in the culture pattern of a land that it cannot be unified. ${ }^{25}$ Family law is one such field. No one who knows anything of the influence of the various religions upon marriage and divorce expects that the Islamic and Christian countries will achieve a unified system of family law in the foreseeable future. Likewise, the steps in criminal procedure in the common and civil-law countries have become so firmly embedded in the thinking of lawyers of each system, that it has come to be almost unthinkable that the common law would adopt a procedural stage similar to the preliminary examination of the civil law, or that the civil law would change the character of the judge and deny him the right to conduct the trial and interrogate witnesses without relying upon the examination and cross-examination of the prosecution and the defense.

Differences in legal systems of deep rooted nature have been known to

${ }^{23}$ For example, the International Institute for the Unification of Private Law, located in Rome.

24 A legend, "World Peace Through World Trade," is cast in bronze over the doorway to the International Business Machines Building at $59^{\circ}$ Madison Avenue, New York City. This theme has also been the subject of advertisements published in the New York Times by the Isbrandtsen Line during the summer of I950.

${ }^{25}$ See David, Le Droit Comparé, Enseignement de la Culture Générale, paper presented to International Bar Association (London, r950), published by Martinus Nijhoff, The Hague (I950). For the author's thoughts on this subject, see Hazard, UNESCO and the Law, 4 Record of the Association of the Bar of the City of New York 29r (r949). 
cause tensions between peoples in the past when a citizen of one country comes into close relation with the laws and courts of another country. A French citizen who falls afoul of the law in England is subjected to a criminal trial, which the French press thinks unfair and which is used to inflame public opinion and arouse tensions. A Moslem fails to obtain entry into the United States because he has two wives, which are entirely legitimate in his own country. Scholars have begun to ask whether tensions arising out of differences in the law resting upon culture patterns of peoples would be so severe if the differences were analyzed. It is questioned whether many cases would not be reduced in their danger to peace between countries, if citizens of the lands concerned had learned that differing rules often result nevertheless in the preservation of principles of human rights and dignity which are equally revered in the countries concerned.

The problem of comparative lawyers and their courses has been put in these words, in a summary record of the comments made by a member of the committee to form an American Journal of Comparative Law. "He [the committee member] believed it important to use the comparative method to show the fundamental equivalents and identities. He would search for the reason why people have such fundamental equivalents and use the comparative method of study as a means of bringing about cooperation in political and other problems and thus expediting a growing sense of unity of peoples." This view rests on the opinion that unity of peoples does not necessarily require unity of laws, but that unity may flow from diversity and the underlying fundamentals which may not be so sharply different as they appear to be on the surface.

This task of comparative-law teaching is almost unexplored to date. The Société de Législation Comparée in Paris, to which UNESCO has given the task of preparing a study in the field, has commenced with the exploratory work necessary. Six questions have been asked of a wide circle of legal scholars the world around. These are: (I) Have cases of tension been observed in your country which result solely from the existence of two different legal systems in the world? (2) In what field of law (administrative, civil, criminal procedure) have these cases of tension been manifested especially? (3) What are their manifestations and their effects? (4) Do there exist in your country legal studies concerned with this question? (5) Have judicial decisions touched on the problem? (6) What suggestions can be made to aid in the planning of the study? ${ }^{26}$

${ }^{26}$ Taken from the text of a circular letter, a copy of which was addressed to the author in July, r950. 
While little has yet been done with this aspect of comparative studies in law, it is obvious that the trend of international law is now requiring such study. The treatment of the individual has become of increasing concern to the international lawyer with the adoption of a Declaration of Human Rights and a Genocide Convention by the General Assembly of the United Nations and the prospective adoption of a Covenant of Human Rights, which may obtain the binding force of treaty if ratified by a sufficient number of states. Nations of the world already find themselves hailed before the bar of public opinion if they treat foreigners and even their own citizens in a manner thought not to measure up to the standards of justice being set by the General Assembly of the United Nations. Eventually the transgressor states may be hailed before an international tribunal of human rights.

No one asks that laws be uniform in all states, but rather that minimum standards be met, and it is expected that there will be wide diversity in the laws which meet the standards. Here is the place at which equivalents become important. It is the point at which serious international tension can be expected to arise, as it has already arisen over conditions in the Union of South Africa, if world opinion comes to the conclusion that standards are not being met. Because of the close interrelation between comparative and international law in the new phase, students intending to specialize in international law must now familiarize themselves with comparative law as well, at least when the question concerns human rights. Added stimulus has been given to courses in comparative law.

\section{The INstilling of Values}

There are those in the United States and elsewhere who despair of any unity with the Soviet system, even on matters of equivalent standards of treatment of human beings, much less on detailed statutes. It is argued that students trained in comparative law can achieve moderate success in seeking the unity of peoples in the manner already indicated, but that such an eventuality on a world-wide scale is not to be expected in view of the fundamental philosophical differences existing between the Soviet and non-Soviet sectors of the world. If this be so, the political advantage to be gained from the study of comparative law is not to be sought in the unification of all peoples through understanding of underlying equivalents, but rather in the coagulation and strengthening of a non-Soviet sector through an appreciation of the values cherished by the citizens of a given group of states insofar as these values are protected through laws, diverse as they may be. 
In reverse illustration of the possibilities, one may point to the Soviet law school with its comparative law course entitled "The Law of Bourgeois States." Only recently the purpose of such courses in comparative law in Soviet law schools has been restated in the following words, "We must know and we do firmly know that all progressive humanity turns its eyes not toward the Justinian and Napoleonic codes, but to the Stalin Constitution and the laws created on its foundation. Our law is the highest type of law, and there is nothing fortuitous in the fact that the people's democracies are learning from us, and among other fields, in that of law. It is, of course, necessary to know both Roman and contemporary bourgeois law, but first of all it is necessary to know Soviet socialist law thoroughly. Bourgeois law must be known not in order to borrow its ideals, but so that, knowing our own and an alien law, we may perfect our own and expose the reactionary, exploiting character of bourgeois law, striking at its most sensitive spots." 27

The Soviet author who has made this observation indicates clearly that comparative law in the Soviet law school serves a political purpose, in uniting the Soviet system with those systems recently brought within its orbit, and in convincing the Soviet students of the desirability of their system of law. It is possible to utilize comparative law in the American law schools for the same purpose, namely for perfecting American law and for convincing American law students of the desirability of their system of law. The field may be broadened to convince citizens of non-Soviet states of the preferability of the systems of law which are in effect in those states over the system of law in the Soviet sphere of influence. In this way the study of comparative law could become an instrument in the current ideological struggle by which those who protect the system of law, namely the future practitioners, prosecutors, and judges, may develop at any early stage in their education an appreciation of the values which their system protects and a determination to see that these values are maintained. It is a matter of speculation alone, but who can now tell whether it might not have been possible for some of the highest standing men in the graduating class of one of America's great law schools during the depression of the I930's to have gained an opinion of what the Soviet system offered without having to go through the apparent ordeal of discovery as the result of membership in the Communist Party.

If such an approach to the instilling of values be adopted, the student

${ }_{27}$ N. V. Kazantsev, Tasks of Scientific Research in the Field of Law, Izvestiya Akademii Nauk SSSR, Otdelenie ekonomiki i prava, No. r, at 36-44 (1950), Eng. trans. in 2 Current Digest of the Soviet Press, No. 16 , at 5-6 (June 3, 1950). 
will seek in the comparative-law course not only an understanding of the principles of the common law as placed in sharp relief by comparison with other systems of law, but he will be able to make up his mind as to the system he prefers. He will consider the legal principles which seem essential to the preservation of a social system designed to maintain values which he cherishes. He may then be fitted more adequately than is usually the case for a career which is no less imminent than his bread-and-butter practice, for what lawyer can now escape the debate in every meeting of war veterans or business associates and in every political gathering in the country, and even in the drawing rooms in which the rest of his life will be lived? With an appreciation of the values he cherishes and of the institutions which he has come to believe protect them, the future lawyer-citizen will know how to pick and choose from among the proposals made to meet the social problems of the nation. He need not make himself ridiculous by opposing all proposals in ignorance of their prospective effect upon cherished values. He need not behave like some of his ancestors who opposed the establishment of the Federal Reserve System or woman suffrage. As a lawyer in his community he will be respected for his opinions, and he must be prepared to respond as intelligently as when he is asked by a client how to minimize a tax burden or draft a will.

\section{The Graduate Course}

Most of the writing on comparative law in legal education has concerned the course for students seeking the LL.B. degree or its equivalent. It is at the undergraduate level that the challenge has been raised, for at that level time is limited and the pressure of the bar examinations so great that nothing can hope to find favor unless it can be supported on grounds of practicality or on grounds of providing the minimum of theoretical understanding without which even the narrowest mind is ashamed to appear at his local bar association.

In contrast to the resistance to comparative law courses for undergraduates, the course for the graduate student preparing to teach has been rather easily accepted by those who control the course of legal education. Some deans, such as Roscoe Pound, have held that the prospective teacher must be a wide reader and without limit to his knowledge. ${ }^{28}$ Comparative

28 "It is the student who is to be a law teacher and to make the science of law his life work who must read and read deeply in the masters who have made the science of law, and must go to the sources and original materials and not be content with what even the masters have written about them." See Pound, General Introduction, I Simpson and Stone, op. cit. supra note I9, at XIII-XIV. 
law easily finds a place under such an approach. The University of Cambridge, through Professor H. C. Gutteridge, has laid major emphasis upon graduate teaching of comparative law, and has recently taken the position that it is at the graduate level that the subject can best be taught, because only at that level does the student have background sufficiently large to permit him to make valuable comparisons. ${ }^{29} \mathrm{It}$ is felt by these experts that a student can do best if he already knows a foreign system of law and comes to England to compare what he knows with the English system. A similar approach has been utilized in some American law schools, and with some marked success, measured in terms of legal studies which have later appeared in the countries from which the students have come.

Of most recent years the political advantages of such comparative law seminars at the graduate level for foreign students have been appreciated. The Department of State together with the Department of the Army has brought to the United States groups of German referendars. These Germans who already have achieved the equivalent of the LL.B. in German law attend special courses in the common law which take into consideration their knowledge of the German system. The results have been reported favorably from the law schools which they have attended. Professor Max Rheinstein has indicated that some political results can be expected to flow from the experience of the Germans. ${ }^{30} \mathrm{He}$ has written, "The discussions of American constitutional law seem to have produced new insights into the problems and the workings of democracy.... I am inclined to believe that this experience may be of lasting influence upon the political thinking of the students."

Similar experiences have been had in England to which German law students have been brought for courses in legal education by the British Foreign Office in arrangement with the Law Society. A report on the subject, ${ }^{3 \mathrm{x}}$ prepared by J. B. Leaver who represented the Law Society in the conduct of the course, assesses the results of the program in these words, "There is, thus, here, a two way traffic of gain. The student gains by his study of another system of law, and particularly by the insight afforded into a nation's characteristics and character. Thereby, and equally, his hosts gain by the critical, and to them original, concepts which he is able to display with respect to their own system of law. If any system of law

29 Paper presented to the International Bar Association (London, 1950).

${ }^{30}$ University of Chicago Law School, Report on The German Referendar Training Program (r950) (mimeographed).

${ }^{32}$ Leaver, Legal Education, report to International Bar Association (London, I950) (mimeographed). 
is to grow towards perfection (and growth is the law of life of any legal system) it must be, in my suggestion, constantly subjected to this process of critical and original examination from outside."

Some of the law schools even without the intervention of the Department of State, have been active in the field for similar political reasons. Thus, Yale has proceeded on the assumption that young lawyers from other lands merit a course in the United States because they can be expected to become leaders in their communities when they return from their studies. If we in the United States hope to foster values which we cherish as essential to the preservation of freedom throughout the world, we must win friends. This is easiest among those who wish to preserve the same values and $\mathrm{know}$ what we seek to do. By introducing the potential leaders from other countries to our system of law, and more importantly, the values which it seeks to protect, it can be anticipated that these men will return to guide their countries in the same direction, albeit with laws which may be dissimilar in form yet achieving the same ends. Likewise, our law teachers who are increasingly influential in the preparation of legislative drafts and the studies on which legislatures rely for information before they do their own drafting may find their background enriched by information which comes to them in the classroom filled with students reared under other systems of law.

The merit of the graduate seminar in comparative law seems to have been accepted by those schools which are fortunate enough to have or to be able to obtain the financial resources necessary for its realization. Such schools of foreign and comparative law are becoming more numerous and several are projected. When they become sufficiently common to permit American graduate students preparing for the teaching profession to participate with the top students of other lands, it may be possible to hope for the wide dissemination of information about other legal systems among the teaching profession as a whole. From this the goal of the common-law course conducted in a critical manner by a professor who knows something of other approaches to the problem may be achieved.

\section{TEaching MEtHods}

Much has already been written about teaching methods. ${ }^{32}$ Throughout the United States, courses in comparative law seem to be conducted almost universally on the basis of readings and discussions similar to those used for the teaching of common-law subjects. The lecture method, com-

${ }^{32}$ See Stevenson, op. cit. supra note II, for a summary of the literature. 
mon to Europe and to the United States before the development of the case method is rarely used. It seems to lack stimulation for students, who lose interest when the professor does all the talking. But more importantly, it fails to excite as positively as the discussion technique the questioning attitude so prized in the American law school.

The questioning attitude from which conviction develops on a firm foundation seems to be particularly important in those situations where comparative law is taught for its political value. Telling a student that one system is better or worse than another may convince the mentally sluggish and antagonize the mentally alert. For both types the effect is not what is desired. Years later when the mentally sluggish meet an ardent exponent of the criticized system, they may reject him quickly, but they may on the other hand welcome his proposal with open arms, because they have never thought through what the teacher said. They are therefore prepared to abandon the nearly forgotten teacher's advice when they meet one who can argue for a point in more telling terms than the teacher and support his reasoning by what appear to be plausible arguments for a new approach apparently required by changed social, economic or political conditions. The mentally alert on the other hand because of the antagonism which they feel for spoon feeding, can jump to the criticized side immediately and become involved in political action at a level from which they cannot extricate themselves years later without great embarrassment, if not worse. The record of confessions before the Un-American Activities Committee during the past year has shown what can happen in this sphere.

In view of this experience, there is much to be said for the system of teaching which has been accepted generally in American law schools. Let the student have all of the facts on the systems to be compared, and guide the student to various opinions relating to these facts. In most cases the student will come forward at the end of the course with some convictions of his own, which are well grounded, and from which he will not rebel because of spoon feeding or which he will not abandon when a good talker comes into his parlor after he finishes school.

Some evidence in support of this conclusion is to be found in a letter addressed to the author by a foreign student trained in the continental method of the lecture system and complaining about the time he took to work out his own ideas under the case method of teaching. He wrote, "As a positive result of your method we were able to acquire far more comprehensive knowledge than otherwise possible and were forced to 
evaluate the Soviet legal system by ourselves, using our own criteria on the basis of your formalistic materials. Thus it might be asserted that some of us have gained by our opposition to your method the independence of critical approach; yet as mere students we had to pay a high price for our gain, missing your evaluation and guidance."

There is undoubtedly reason for the student's criticism of what may have been a leaning over backwards to avoid preaching to the students and to make them think. This criticism may be met by counterbalancing the discussion in the classroom with law review articles or monographs written by the teacher or other specialists setting forth some evaluation to which the students may turn in desperation after they have tried to think things through by themselves. The use of outside law review reading also has an advantage in that then there is recorded accurately what the teacher thinks. It is the rare student who can grasp quickly and record in his notebook accurately during the discussion anything but the simplest black or white statement, and few evaluations can be expressed so simply.

The number of law review articles has grown constantly as evidenced by the indexes and bibliographies. Comparative law studies no longer lack for the basic materials, at least. Yet there will probably always be required mimeographed materials reflecting the personality and approach of the indjvidual teacher. Few teachers of comparative law have had the same experience with a foreign system, and few are therefore able to use the same materials in their course. In consequence the printed articles and monographs and the first printed casebook will require supplementing to meet the capabilities and interests of the particular teacher. The finding of materials to put in such collections remains an exacting experience. The need has become so acutely felt that the London conferences both had sessions concerned with finding the law, and the matter has been entrusted to the International Committee for Comparative Law as a primary matter of concern.

It has become obvious that no one center can ever hope to collect and prepare for use all of the law of all of the major jurisdictions. It has become almost impossible to collect in a normal-sized library what is necessary to find the law of the various jurisdictions of the United States. The schemes presented in London proposed, nevertheless, in some instances the creation of an all-inclusive center of foreign law on each continent. In the debate it was indicated that this approach seemed impossible of achievement, and the International Committee for Comparative Law was encouraged to explore the possibilities of national repositories. These re- 
positories would have staffs available to provide, through liaison with a central liaison bureau or directly with the questioner, information on the state of the law of the country concerned. It was also urged that scholars in each country prepare background studies, to be translated into the major languages known to scholarship throughout the world, in which the fundamental material necessary for understanding the law of a country could be found. It is appreciated that the teaching of comparative law must rest upon profound research in the field, and that this research has only been begun.

\section{Conclusion}

The study of any subject on the frontier of knowledge holds the interest of the scholar. The comparative study of law, in its new ramifications, can be expected to gain adherents at the teaching and graduatestudent level with the passing of the years. Close interrelation between law and the values we cherish and for which we fight can be expected to assure continuing interest of those legal scholars who lift their eyes above the level of the artisan; and who does not, in the r950's? There need be little concern for the bright future of research and study in comparative law at the advanced level.

The place of comparative law in the curriculum leading to the LL.B. degree is still the debated question. Those who teach the subject are thoroughly convinced of its practicality and desirability, as has been evidenced by the testimonials in the form of articles and participation in affairs concerned with such discussion. ${ }^{33}$ Whether the faculty officials who prescribe the curriculum can be expected to develop such an interest remains to be seen. To many of those who try to convince them, it seems that comparative law has proved its practical value in many ways, including the development of perceptive and imaginative practitioners in a confusing world calling for perception and imagination. Many proponents of comparative law for the undergraduate law student believe that it can no longer be thought that the development of attitudes toward the values we cherish and are asked to defend is any the less practical than the counselling of clients. Without the preservation of such values the counselling of clients may become a very different activity from what it now is, and some of those who now counsel may not be within the circle of those licensed to practice at all.

${ }^{33}$ See bibliography in Schlesinger, op. cit. supra note 2 , at 467 . 